\title{
Spatial and temporal variation of dissolved heavy metals in the Lijiang River China: Implication of rainstorm on drinking water quality
}

Liming Deng

Guilin University of Technology

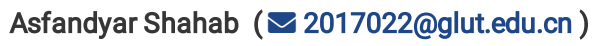

Guilin University of Technology https://orcid.org/0000-0003-4422-5933

He Xiao

Guilin University of Technology

Jieyue Li

Guilin University of Technology

Saeed Rad

Guilin University of Technology

Jinping Jiang

Guilin University of Technology

Guo Yu

Guilin University of Technology

Pingping Jiang

Guilin University of Technology

Hongwei Huang

Guilin University of Technology

Xiangkui Li

Guilin University of Technology

Bilal Ahmad

University of Swat

Jamil Siddique

Quaid-i-Azam University Islamabad: Quaid-i-Azam University

Research Article

Keywords: Dissolved heavy metals, Water quality, Health risk assessment, Rainstorm, Lijiang River

Posted Date: April 5th, 2021

DOl: https://doi.org/10.21203/rs.3.rs-332750/v1

License: @ (i) This work is licensed under a Creative Commons Attribution 4.0 International License. Read Full License

Version of Record: A version of this preprint was published at Environmental Science and Pollution Research on July 17th, 2021. See the published version at https://doi.org/10.1007/s11356-021-15383-3. 


\section{Abstract}

Lijiang River is an essential drinking water source and natural scenery in the Guilin City. For the first time, implications of rainstorm were taken into consideration by investigating spatial and temporal variation of dissolved heavy metals (HMs) in the Lijiang River water. A total of 68 water samples were collected during low flow (normal) season and high flow (rainstorm) season from 34 sampling sites. Dissolved HMs including Cr, Mn, Co, Cu, Zn, As, Cd, Sb, and $\mathrm{Pb}$ were found to meet the respective drinking water standards, while higher concentration was observed after the rainstorm season, except for $\mathrm{Cr}$. Multivariate statistical analysis showed $\mathrm{Co}, \mathrm{Cu}, \mathrm{Cr}, \mathrm{Zn}, \mathrm{Sb}$, and $\mathrm{Pb}$ in normal season are mainly controlled by anthropogenic sources. Furthermore, higher concentration of $\mathrm{Mn}, \mathrm{Cu}, \mathrm{Cd}, \mathrm{Pb}, \mathrm{Co}$ and $\mathrm{Zn}$ during the high flow season is attributed to rainstorm. The water quality index (WQI) showed good grades, and comparatively lower in rainstorm season. The results of health risk assessment revealed that HMs in Lijiang River pose limited health risk, however, As poses potential health risk during rainstorm season. It is suggested to adopt preventive measures in mining activities and industrial waste-water discharge at the river's upstream and downstream.

\section{Introduction}

The quality of water has significant impacts on human health and the ecological environment. Natural processes such as weathering, erosion, hydrological, climatic changes, volcanic activities, and landscape characteristics could be to the main factors of water quality deterioration (Ai et al., 2015; Meng et al., 2016). Besides, extensive technological developments coupled with a growing population have led to an increased demand for water, which in turn may bring about a decline in the quality and quantity of water resources globally. Anthropogenic impacts such as coal combustion, industrial or agricultural wastes, sewage discharge, mining, and transportation are among the manmade causes of rivers water pollution (Rakotondrabe et al., 2018; Villa-Achupallas et al., 2018; Wang et al., 2017). Taking into account the amount of freshwater per capita in China ( $80 \%$ sourced from the rivers) which is $1 / 3$ of the global average, making it top priority issue to focus on.

HMs in both dissolved and suspended phases are known as the most harmful types in aquatic environment among various of pollutants (Shotyk et al., 2017) Although certain trace elements in limited concentration are indispensable for organisms, they pose threats to human or ecological security when exceed safety thresholds (Chowdhury et al., 2016). HMs such as As, Cd, Cr, Cu, Pb, Hg, Ni, Zn which can cause cancer, minamata, bone pain, and other illnesses are listed as the priority toxic pollutants (Strady et al., 2017). According to the health risk index, arsenic is considered the most significant pollutant for noncarcinogenic and carcinogenic problems and is a major contributor to chronic risk (Shahab et al., 2019; Zeng et al., 2015). It was reported that about 6.8 million people in Bangladesh lived in high dosage of As (Chakraborti et al., 2010). The researches in Brazil also illustrated that Cr, Mn, and Ni pose noncarcinogenic risks (Ferreira et al., 2020). Therefore, HMs level in drinking water resource should be clarified for the sake of public health safety.

The investigation of distribution, source identification, and health risk assessment of dissolved HMs in the rivers of China have been carried out previously (Wang et al., 2017; Xiao et al., 2019; Zhao et al., 2018). However, more attentions should be paid on the rivers in karst areas. Karst aquifers have special structures, geological backgrounds, hydrodynamic conditions, and hydro-chemical characteristics (Zhang et al., 2014), which may affect the migration and transformation of pollutants into the water. The Lijiang River is a typical karst river which the bedrock is characterized by the pure and thick carbonate strata (Xu et al., 2016). Due to agricultural, industrial and leisure activities, concentration of HMs in the sediments of Lijiang River are much higher than background and standard level (Xiao et al., 2021; Xu et al., 2016). Due to recent development trend in China, this relatively small watershed being one of the top tourist destinations, is hosting nearly 100 million travelers annually (Shahab et al., 2020). Recent urbanization has caused environmental challenges such as road dust HMs sourced from fuel consumption (Shahab et al., 2020). These are on top of the usual industrial, residential, and agricultural contaminants that are daily entering the river without treatment.

Lijiang River is the main source of drinking water for the millions citizens in the Guilin city (Xiao et al., 2021). As rainy and humid monsoon is common climate in Guilin all the year, rainstorms could significantly affect the quality of Lijiang water. Rainstorm runoff is one of the key drivers on the rivers' water quality deterioration, carries and releases contaminants from the point and non-point sources to the consumable waterbodies (Ma et al., 2015). Reports of HMs in Lijiang basin are alarming (Wu et al., 2020; Xiao et al., 2021; Xu et al., 2016), hence, it is essential particularly to investigate the influence of rainstorm in the study area. To the best of our knowledge, this is the first time to take the climate conditions into account in studying the dissolved HMs of Lijiang River water. In this study, a total of 68 water samples along the Lijiang River were collected systematically, to analyze nine dissolved HMs (ie: $\mathrm{Cr}$, Mn, Co, Cu, Zn, As, Cd, Sb, and $\mathrm{Pb}$ ). The aims are: (1) to investigate the spatial and temporal distribution characteristics and identify the sources of dissolved HMs in the Lijiang River water; (2) to evaluate the water quality and health risks of dissolved HMs in Lijiang River in different flow seasons through the water quality index and health risk assessment; and (3) to discuss the effects of rainstorm on the dissolved HMs and aquatic environment of the study area.

\section{Materials And Methods}

\subsection{Study area}

The Lijiang River $\left(109^{\circ} 45^{\prime}-110^{\circ} 56^{\prime} \mathrm{E}, 24^{\circ} 38^{\prime}-25^{\circ} 55^{\prime} \mathrm{N}\right)$ flows from the north toward the south of Guangxi province in southern part of China (Fig. 1 ). As one of eight tributaries of the Pearl River (or the Zhujiang River), Lijiang River is approximately 164 kilometers in length and originates from Maoer Mountains in hilly areas of Xing'an County that locates in the north of Guangxi province. The Lijiang River passes through the Guilin city from Lingchuan County to the Yangshuo County. At the downstream in Pingle County, it connects with Guijiang River and further joints to the Pearl River. The subtropical climate of the study area has monsoon-like weather. The average annual precipitation and temperature of the Lijiang basin is $\sim 1890.4 \mathrm{~mm}$ and $\sim 19.2^{\circ} \mathrm{C}($ Xiao et al., 2021$)$. Lijiang River is situated in the typical karst area characterized by the pure and thick carbonate strata (Xu et al., 2016).Karst aquifers have special structures, geological backgrounds, hydrodynamic conditions, and hydro-chemical characteristics (Zhang et al., 2014), which may bring higher risk of pollutants going into the water. Due to the increase of anthropogenic activities (tourism, mining and industrial), HMs in Lijiang aquatic environment accumulated higher than 
the background values (Xiao et al., 2021; Xu et al., 2016). As the significant drinking water source for local resident, it is essential to pay more attentions on the water quality of Lijiang River.

\subsection{Sample collection and analysis}

A total of 68 water samples were collected from 34 sites throughout the Lijiang River in two hydrologic periods. Sample Collection was carried out during May (low flow season) and August (high flow season) after the rainstorm in 2019 (Fig. 1). Each collected water sample was poured into a pre-cleaned polyethylene bottle and acidified with $1 \mathrm{~mol} / \mathrm{L} \mathrm{HNO}_{3}$. After sealing and labeling the bottles, the water samples were stored in a dark refrigerator at $4^{\circ} \mathrm{C}$. Prior to measuring the concentrations of $\mathrm{Cr}, \mathrm{Mn}, \mathrm{Co}, \mathrm{Cu}, \mathrm{Zn}, \mathrm{As}, \mathrm{Cd}, \mathrm{Sb}$, and $\mathrm{Pb}$, the water samples were filtered with $0.45 \mu \mathrm{m}$ polycarbonate membrane, and then analyzed by an inductively coupled plasma mass spectrometry (Nexion 350x; Perkin Elmer Ltd., USA). Standard materials (GSB 04-1767-2004) and blank samples were set for quality control. The detection limits were $\leq 10 \mathrm{ng} / \mathrm{L}$ and the recoveries ranged between 93 and $105 \%$.

\subsection{Water quality index}

The water quality index (WQI) is used to evaluate the quality of aquatic environment in this work. It reveals the impact of different parameters in the water samples. The WQI is calculated according to the equation as below (Wang et al., 2017):

$\mathrm{WQI}=\Sigma\left[\left(\mathrm{W}_{i} \times\left(\mathrm{C}_{i} / \mathrm{S}_{i}\right)\right] \times 100(1)\right.$

Where $\mathrm{W}_{i}$ is the weight of water parameter $i$ which displays the relative importance of parameter $i$ among all the water parameters for drinking purposes, it is calculated according to the factor loading of parameter $i$ and the eigenvalues from the PCA results (Table S2). $C_{i}$ is the measured concentration of HM $i$ in samples. $S_{i}$ is the guideline value of $\mathrm{HM} i$ in the Chinese drinking water standards (GB $5749-2006$ ). According to the value of WQI, the water quality of aquatic environment can be classified into five categories (Xiao et al., 2019), ie: $0 \leq W Q I<50$ suggests the water quality is excellent; $50 \leq$ WQI $<100$ suggests is good; $100 \leq \mathrm{WQI}<200$ is poor; $200 \leq \mathrm{WQI}<300$ is very poor; WQI $\geq 300$ suggests the water is undrinkable.

\subsection{Health risk assessment}

The health risk assessment method was applied to quantify health risks (carcinogenic and non-carcinogenic) due to different exposure routes from HMs. In the health risk assessment model, the direct hand-mouth ingestion intake and dermal contact intake are usually considered as the two main exposure pathways for $\mathrm{HMs}$ in aquatic environment (Xiao et al., 2019). The exposure average daily dose for direct ingestion ( $\left.A D D_{\text {ing }}\right)$ and dermal absorption ( $A D D_{\text {der }}$ ) can be evaluated using the following equations (Chai et al., 2021):

$A D D_{\text {ing }}=\left(C_{w} \times I R \times E F \times E D\right) /(B W \times A T)(2)$

$A D D_{\text {der }}=\left(C_{w} \times S A \times K_{p} \times E T \times E F \times E D \times 10^{-3}\right) /(B W \times A T)(3)$

Where $C_{w}$ is the mean concentration of each HM in the water sample $(\mu \mathrm{g} / \mathrm{L})$. The explanation and values of the IR, EF, ED, BW, AT and ET are showed in Table $\mathrm{S} 1$. The values of these parameters are referenced from US EPA (2002) and Wang et al. (2017). $\mathrm{K}_{\mathrm{p}}$ is the dermal permeability coefficient of compound in water (cm/h, as presented in Table 3). 
Table 3

Reference dose (RfD), hazard quotient (HQ) and hazard Index (HI) for dissolved heavy metals in Lijiang River water.

\begin{tabular}{|c|c|c|c|c|c|c|c|c|c|c|c|c|c|c|c|}
\hline \multirow[t]{3}{*}{ Elements } & & \multirow[t]{3}{*}{$\operatorname{RfD}_{\text {ing }}$} & \multirow[t]{3}{*}{$\mathrm{RfD}_{\text {der }}$} & \multicolumn{6}{|l|}{ Adult } & \multicolumn{6}{|c|}{ Children } \\
\hline & & & & \multirow{2}{*}{\multicolumn{2}{|c|}{$\begin{array}{l}\mathrm{HQ}_{\text {ing }} \\
\text { normal } \\
\text { rainstorm }\end{array}$}} & \multirow{2}{*}{\multicolumn{2}{|c|}{$\begin{array}{l}\mathrm{HQ}_{\mathrm{der}} \\
\text { normal } \\
\text { rainstorm }\end{array}$}} & \multirow{2}{*}{\multicolumn{2}{|c|}{$\begin{array}{l}\text { HI } \\
\text { normal } \\
\text { rainstorm }\end{array}$}} & \multirow{2}{*}{\multicolumn{2}{|c|}{$\begin{array}{l}\mathrm{HQ}_{\text {ing }} \\
\text { normal } \\
\text { rainstorm }\end{array}$}} & \multirow{2}{*}{\multicolumn{2}{|c|}{$\begin{array}{l}\mathrm{HQ}_{\mathrm{der}} \\
\text { normal } \\
\text { rainstorm }\end{array}$}} & \multirow{2}{*}{\multicolumn{2}{|c|}{$\begin{array}{l}\text { HI } \\
\text { normal } \\
\text { rainstorm }\end{array}$}} \\
\hline & & & & & & & & & & & & & & & \\
\hline $\mathrm{Cr}^{1 *}$ & $\begin{array}{l}1 \times 10^{-} \\
3\end{array}$ & 3 & 0.075 & $\begin{array}{l}1.48 \mathrm{E}- \\
02\end{array}$ & $\begin{array}{l}2.28 \mathrm{E}- \\
03\end{array}$ & $\begin{array}{l}3.09 \mathrm{E}- \\
03\end{array}$ & $\begin{array}{l}4.77 \mathrm{E}- \\
04\end{array}$ & $\begin{array}{l}1.79 \mathrm{E}- \\
02\end{array}$ & $\begin{array}{l}2.76 \mathrm{E}- \\
03\end{array}$ & $\begin{array}{l}2.21 \mathrm{E}- \\
02\end{array}$ & $\begin{array}{l}3.41 \mathrm{E}- \\
03\end{array}$ & $\begin{array}{l}9.11 \mathrm{E}- \\
03\end{array}$ & $\begin{array}{l}1.41 \mathrm{E}- \\
03\end{array}$ & $\begin{array}{l}3.12 \mathrm{E}- \\
02\end{array}$ & $\begin{array}{l}4.82 \mathrm{E}- \\
03\end{array}$ \\
\hline$M n^{1 *}$ & $\begin{array}{l}1 \times 10^{-} \\
3\end{array}$ & 24 & 0.96 & $\begin{array}{l}2.74 \mathrm{E}- \\
02\end{array}$ & $\begin{array}{l}4.04 \mathrm{E}- \\
02\end{array}$ & $\begin{array}{l}3.57 \mathrm{E}- \\
03\end{array}$ & $\begin{array}{l}5.27 \mathrm{E}- \\
03\end{array}$ & $\begin{array}{l}3.09 \mathrm{E}- \\
02\end{array}$ & $\begin{array}{l}4.57 \mathrm{E}- \\
02\end{array}$ & $\begin{array}{l}4.08 \mathrm{E}- \\
02\end{array}$ & $\begin{array}{l}6.03 \mathrm{E}- \\
02\end{array}$ & $\begin{array}{l}1.05 \mathrm{E}- \\
02\end{array}$ & $\begin{array}{l}1.56 \mathrm{E}- \\
02\end{array}$ & $\begin{array}{l}5.14 \mathrm{E}- \\
02\end{array}$ & $\begin{array}{l}7.59 \mathrm{E}- \\
02\end{array}$ \\
\hline $\mathrm{Co}^{1 *}$ & $\begin{array}{l}4 \times 10^{-} \\
4\end{array}$ & 0.3 & 0.06 & $\begin{array}{l}1.19 \mathrm{E}- \\
02\end{array}$ & $\begin{array}{l}1.14 \mathrm{E}- \\
01\end{array}$ & $\begin{array}{l}1.24 \mathrm{E}- \\
04\end{array}$ & $\begin{array}{l}1.19 \mathrm{E}- \\
03\end{array}$ & $\begin{array}{l}1.20 \mathrm{E}- \\
02\end{array}$ & $\begin{array}{l}1.15 \mathrm{E}- \\
01\end{array}$ & $\begin{array}{l}1.77 \mathrm{E}- \\
02\end{array}$ & $\begin{array}{l}1.70 \mathrm{E}- \\
01\end{array}$ & $\begin{array}{l}3.66 \mathrm{E}- \\
04\end{array}$ & $\begin{array}{l}3.52 \mathrm{E}- \\
03\end{array}$ & $\begin{array}{l}1.81 \mathrm{E}- \\
02\end{array}$ & $\begin{array}{l}1.74 \mathrm{E}- \\
01\end{array}$ \\
\hline $\mathrm{Cu}{ }^{2^{*}}$ & $\begin{array}{l}1 \times 10^{-} \\
3\end{array}$ & 40 & 8 & $\begin{array}{l}4.52 \mathrm{E}- \\
04\end{array}$ & $\begin{array}{l}6.03 \mathrm{E}- \\
04\end{array}$ & $\begin{array}{l}1.18 \mathrm{E}- \\
05\end{array}$ & $\begin{array}{l}1.57 \mathrm{E}- \\
05\end{array}$ & $\begin{array}{l}4.64 \mathrm{E}- \\
04\end{array}$ & $\begin{array}{l}6.18 \mathrm{E}- \\
04\end{array}$ & $\begin{array}{l}6.75 \mathrm{E}- \\
04\end{array}$ & $\begin{array}{l}9.00 \mathrm{E}- \\
04\end{array}$ & $\begin{array}{l}3.48 \mathrm{E}- \\
05\end{array}$ & $\begin{array}{l}4.64 \mathrm{E}- \\
05\end{array}$ & $\begin{array}{l}7.10 \mathrm{E}- \\
04\end{array}$ & $\begin{array}{l}9.47 \mathrm{E}- \\
04\end{array}$ \\
\hline $\mathrm{Zn}{ }^{1 *}$ & $\begin{array}{l}6 \times 10^{-} \\
4\end{array}$ & 300 & 60 & $\begin{array}{l}1.35 \mathrm{E}- \\
03\end{array}$ & $\begin{array}{l}1.94 \mathrm{E}- \\
02\end{array}$ & $\begin{array}{l}2.12 \mathrm{E}- \\
05\end{array}$ & $\begin{array}{l}3.04 \mathrm{E}- \\
04\end{array}$ & $\begin{array}{l}1.37 \mathrm{E}- \\
03\end{array}$ & $\begin{array}{l}1.97 \mathrm{E}- \\
02\end{array}$ & $\begin{array}{l}2.02 \mathrm{E}- \\
03\end{array}$ & $\begin{array}{l}2.90 \mathrm{E}- \\
02\end{array}$ & $\begin{array}{l}6.25 \mathrm{E}- \\
05\end{array}$ & $\begin{array}{l}8.97 \mathrm{E}- \\
04\end{array}$ & $\begin{array}{l}2.08 \mathrm{E}- \\
03\end{array}$ & $\begin{array}{l}2.99 \mathrm{E}- \\
02\end{array}$ \\
\hline $\mathrm{As}^{2^{*}}$ & $\begin{array}{l}1 \times 10^{-} \\
3\end{array}$ & 0.3 & 14 & $\begin{array}{l}1.03 \mathrm{E}- \\
01\end{array}$ & $\begin{array}{l}1.05 \mathrm{E}- \\
01\end{array}$ & $\begin{array}{l}1.15 \mathrm{E}- \\
05\end{array}$ & $\begin{array}{l}1.17 \mathrm{E}- \\
05\end{array}$ & $\begin{array}{l}1.03 \mathrm{E}- \\
01\end{array}$ & $\begin{array}{l}1.05 \mathrm{E}- \\
01\end{array}$ & $\begin{array}{l}1.54 \mathrm{E}- \\
01\end{array}$ & $\begin{array}{l}1.57 \mathrm{E}- \\
01\end{array}$ & $\begin{array}{l}3.41 \mathrm{E}- \\
05\end{array}$ & $\begin{array}{l}3.47 \mathrm{E}- \\
05\end{array}$ & $\begin{array}{l}1.54 \mathrm{E}- \\
01\end{array}$ & $\begin{array}{l}1.57 \mathrm{E}- \\
01\end{array}$ \\
\hline $\mathrm{Cd}^{1 *}$ & $\begin{array}{l}1 \times 10^{-} \\
3\end{array}$ & 0.5 & 0.025 & $\begin{array}{l}1.10 \mathrm{E}- \\
03\end{array}$ & $\begin{array}{l}5.48 \mathrm{E}- \\
03\end{array}$ & $\begin{array}{l}1.14 \mathrm{E}- \\
04\end{array}$ & $\begin{array}{l}5.72 \mathrm{E}- \\
04\end{array}$ & $\begin{array}{l}1.21 \mathrm{E}- \\
03\end{array}$ & $\begin{array}{l}6.05 \mathrm{E}- \\
03\end{array}$ & $\begin{array}{l}1.64 \mathrm{E}- \\
03\end{array}$ & $\begin{array}{l}8.18 \mathrm{E}- \\
03\end{array}$ & $\begin{array}{l}3.38 \mathrm{E}- \\
04\end{array}$ & $\begin{array}{l}1.69 \mathrm{E}- \\
03\end{array}$ & $\begin{array}{l}1.97 \mathrm{E}- \\
03\end{array}$ & $\begin{array}{l}9.87 \mathrm{E}- \\
03\end{array}$ \\
\hline $\mathrm{Sb}^{3^{*}}$ & $\begin{array}{l}1 \times 10^{-} \\
3\end{array}$ & 0.4 & 0.008 & $\begin{array}{l}1.23 \mathrm{E}- \\
02\end{array}$ & $\begin{array}{l}1.71 E- \\
02\end{array}$ & $\begin{array}{l}3.22 \mathrm{E}- \\
03\end{array}$ & $\begin{array}{l}4.47 \mathrm{E}- \\
03\end{array}$ & $\begin{array}{l}1.55 \mathrm{E}- \\
02\end{array}$ & $\begin{array}{l}2.16 \mathrm{E}- \\
02\end{array}$ & $\begin{array}{l}1.84 \mathrm{E}- \\
02\end{array}$ & $\begin{array}{l}2.56 \mathrm{E}- \\
02\end{array}$ & $\begin{array}{l}9.49 \mathrm{E}- \\
03\end{array}$ & $\begin{array}{l}1.32 \mathrm{E}- \\
02\end{array}$ & $\begin{array}{l}2.79 \mathrm{E}- \\
02\end{array}$ & $\begin{array}{l}3.88 \mathrm{E}- \\
02\end{array}$ \\
\hline $\mathrm{Pb}{ }^{1 *}$ & $\begin{array}{l}1 \times 10^{-} \\
3\end{array}$ & 1.4 & 0.42 & $\begin{array}{l}9.78 \mathrm{E}- \\
04\end{array}$ & $\begin{array}{l}2.88 \mathrm{E}- \\
02\end{array}$ & $\begin{array}{l}1.70 \mathrm{E}- \\
05\end{array}$ & $\begin{array}{l}5.01 \mathrm{E}- \\
04\end{array}$ & $\begin{array}{l}9.95 \mathrm{E}- \\
04\end{array}$ & $\begin{array}{l}2.93 \mathrm{E}- \\
02\end{array}$ & $\begin{array}{l}1.46 \mathrm{E}- \\
03\end{array}$ & $\begin{array}{l}4.30 \mathrm{E}- \\
02\end{array}$ & $\begin{array}{l}5.02 \mathrm{E}- \\
05\end{array}$ & $\begin{array}{l}1.48 \mathrm{E}- \\
03\end{array}$ & $\begin{array}{l}1.51 \mathrm{E}- \\
03\end{array}$ & $\begin{array}{l}4.44 \mathrm{E}- \\
02\end{array}$ \\
\hline \multicolumn{16}{|c|}{${ }^{1 *}$ Wang et al. 2017; ${ }^{2^{*}}$ Xiao et al. 2019; ${ }^{3^{*}}$ De Miguel et al. 2007.} \\
\hline
\end{tabular}

The hazard quotient $(\mathrm{HQ})$ and hazard index $(\mathrm{HI})$ shows the potential non-carcinogenic risks of HMs. These methods are developed according to the individual's possibility; due to exposure to a certain-dosage of contaminants (Alidadi et al., 2019). The HQ is, in fact, the ratio of the exposure dose (ADD) as compared to the reference, while $\mathrm{HI}$ is the accumulated $\mathrm{HQ}$ s for each element. When the value of $\mathrm{HQ}$ or $\mathrm{HI} \geq 1$, the non-carcinogenic risk or adverse effects on human health should be considered; seriously, while for the values $\leq 1$, the hazard is negligible. The $\mathrm{HQ}$ and $\mathrm{HI}$ obtained via using the below equations:

$H Q=A D D / R f D(4)$

$\mathrm{HI}=\Sigma\left(\mathrm{HQ}_{\mathrm{ing}}+\mathrm{HQ}_{\mathrm{der}}\right)(5)$

Where $\operatorname{RfD}$ is the reference dose $\left(\mu \mathrm{g} \cdot \mathrm{kg}^{-1} \cdot \mathrm{d}^{-1}\right), \operatorname{RfD}_{\text {ing }}$ and $\mathrm{RfD}_{\text {der }}$ are shown in the Table 3.

\subsection{Multivariate and geostatistical analysis}

In order to compare the spatial differences of 34 stations at different levels and identify the source of HMs, software including Origin2017, SPSS 19.0 and Microsoft Excel 2010 were applied to perform statistical analyses. The analysis of variance (ANOVA) were used to analyze the significant variation of HMs concentration among different sampling sites. Pearson coefficients were determined by SPSS 19.0whichquantify the correlations among HMs. Principal Component Analysis (PCA) was adopted to investigate associations between the sampling sites and HM loads (Li et al., 2011; Ribeiro et al., 2018). ArcGIS 10.5 was employed to provide spatial distribution maps of HMs along the river. Inverse distance weighting method (IDW) was applied to estimate the value of non-sampling points by calculating the weighted average value of observed data from surrounding area (Teegavarapu and Chandramouli, 2005), which is widely used in hydro-chemistry.

\section{Results And Discussion}

\subsection{Concentration of dissolved HMs in Lijiang River water}

The concentration of dissolved HMs in Lijiang River water during normal and rainstorm seasons are compared with drinking water standards (China, USEPA, and WHO) and listed in Table 1. The average $\mathrm{pH}$ and temperature of Lijiang River water sample was 8.31 and $26.0^{\circ} \mathrm{C}$. The coefficient of variation (CV) for dissolved HMs in normal and rainstorm seasons ranged from 23.46 to 320 and 25.87 to 117.8 , respectively, indicating that the distribution of HM concentration in Lijiang River water is disturbed by human activities. The ANOVA analysis results indicated that the concentrations of HMs except for As in 
normal and rainstorm seasons were significantly different $(p<0.05 \%$, ANOVA), which revealed rainstorm had an impact on the concentration of HMs in the water of Lijiang River.

Table 1

Concentration of dissolved heavy metals in Lijiang River, China $(n=34)$.

\begin{tabular}{|c|c|c|c|c|c|c|c|c|c|c|c|c|c|c|c|c|}
\hline \multirow{2}{*}{$\begin{array}{l}\text { Elements } \\
(\mu \mathrm{g} / \mathrm{L})\end{array}$} & \multicolumn{6}{|c|}{ Normal season } & \multicolumn{6}{|c|}{ Rainstorm season } & \multirow{2}{*}{$\begin{array}{l}\text { One- } \\
\text { way } \\
\text { ANOVA } \\
\text { analysis } \\
3\end{array}$} & \multicolumn{3}{|c|}{$\begin{array}{l}\text { Guidelines for } \\
\text { Drinking Water }\end{array}$} \\
\hline & $\min$ & $\max$ & mean & median & $\mathrm{SD}^{1}$ & $\mathrm{CV}^{2}$ & $\min$ & $\max$ & mean & median & $S^{1}$ & $\mathrm{CV}^{2}$ & & $\begin{array}{l}\text { China } \\
4\end{array}$ & $\begin{array}{l}\text { WHO } \\
5\end{array}$ & $\begin{array}{l}\text { US } \\
\text { PE } \\
6\end{array}$ \\
\hline $\mathrm{Cr}$ & 0.02 & 2.72 & 1.62 & 1.66 & 0.38 & 23.46 & 0.15 & 0.48 & 0.25 & 0.23 & 0.07 & 27.86 & 0.000 & 50 & 50 & 10 \\
\hline $\mathrm{Mn}$ & 2.26 & 59.80 & 23.96 & 20.78 & 10.75 & 44.87 & 20.32 & 83.14 & 35.39 & 30.3 & 16.44 & 46.45 & 0.001 & 100 & 400 & na \\
\hline Co & 0.02 & 0.22 & 0.13 & 0.12 & 0.039 & 30 & 0.28 & 3.06 & 1.25 & 1.18 & 0.63 & 50.38 & 0.000 & 1000 & na & na \\
\hline $\mathrm{Cu}$ & 0.10 & 1.10 & 0.66 & 0.64 & 0.16 & 24.24 & 0.53 & 2.21 & 0.88 & 0.75 & 0.36 & 40.83 & 0.002 & 1000 & 2000 & na \\
\hline $\mathrm{Zn}$ & 5.14 & 51.47 & 14.81 & 14.48 & 8.13 & 54.89 & 91.01 & 331.4 & 212.6 & 216.9 & 73.31 & 34.48 & 0.000 & 1000 & 3000 & na \\
\hline As & 0.17 & 2.91 & 1.13 & 1.08 & 0.40 & 35.40 & 0.69 & 8.81 & 1.15 & 0.93 & 1.36 & 117.8 & 0.935 & 10 & 10 & 10 \\
\hline $\mathrm{Cd}$ & 0.00 & 0.06 & 0.02 & 0.02 & 0.017 & 85 & 0.05 & 0.18 & 0.10 & 0.09 & 0.03 & 36.16 & 0.000 & 5 & 3 & 5 \\
\hline $\mathrm{Sb}$ & 0.00 & 0.30 & 0.18 & 0.18 & 0.067 & 37.22 & 0.14 & 0.50 & 0.25 & 0.24 & 0.06 & 25.87 & 0.000 & 5 & 20 & 6 \\
\hline $\mathrm{Pb}$ & 0.00 & 0.68 & 0.05 & 0.00 & 0.16 & 320 & 0.56 & 4.02 & 1.47 & 1.07 & 0.89 & 60.47 & 0.000 & 10 & 10 & na \\
\hline
\end{tabular}

1 SD: standard deviation; 2 CV: the coefficient of variation (\%); 3 ANOVA single factor p-value; 4 Chinese Ministry of Health (China 2002); 5 WHO (the World Health Organization); 6 the United States Environmental Protection Agency (EPA 2004).

The average concentration of $\mathrm{HMs}$ in the normal season water samples were orderly as $\mathrm{Mn}(23.96 \mu \mathrm{g} / \mathrm{L})>\mathrm{Zn}(14.81 \mu \mathrm{g} / \mathrm{L})>\mathrm{Cr}(1.62 \mu \mathrm{g} / \mathrm{L})>\mathrm{As}(1.13 \mu \mathrm{g} / \mathrm{L})>$ $\mathrm{Cu}(0.66 \mu \mathrm{g} / \mathrm{L})>\mathrm{Sb}(0.18 \mu \mathrm{g} / \mathrm{L})>\mathrm{Co}(0.13 \mu \mathrm{g} / \mathrm{L})>\mathrm{Pb}(0.05 \mu \mathrm{g} / \mathrm{L})>\mathrm{Cd}(0.02 \mu \mathrm{g} / \mathrm{L})$. Whereas in rainstorm season the trend was: $\mathrm{Zn}(212.6 \mu \mathrm{g} / \mathrm{L})>\mathrm{Mn}(35.39$ $\mu \mathrm{g} / \mathrm{L})>\mathrm{Pb}(1.47 \mu \mathrm{g} / \mathrm{L})>\mathrm{Co}(1.25 \mu \mathrm{g} / \mathrm{L})>\mathrm{As}(1.15 \mu \mathrm{g} / \mathrm{L})>\mathrm{Cu}(0.88 \mu \mathrm{g} / \mathrm{L})>\mathrm{Sb}(0.25 \mu \mathrm{g} / \mathrm{L})>\mathrm{Cr}(0.25 \mu \mathrm{g} / \mathrm{L})>\mathrm{Cd}(0.10 \mu \mathrm{g} / \mathrm{L})$. Mn and Zn are consistently the most abundant metals in water samples during both periods, while $\mathrm{Cd}$ was the lowest. Although there were fluctuations in concentration of $\mathrm{HMs}$; but were all within the drinking water standard limits in both normal and rainstorm seasons. It is found that the concentration of $\mathrm{Pb}, \mathrm{Zn}, \mathrm{Co}, \mathrm{Cd}, \mathrm{Mn}, \mathrm{Sb}$, and $\mathrm{Cu}$ increased in rainstorm water samples, especially for $\mathrm{Pb}, \mathrm{Zn}$, and $\mathrm{Co}$, which 10 times higher than normal season. However, $\mathrm{Cr}$ decreased in rainstorm season, which probably due to the dilution effect (Olías et al., 2004).

According to Table S3, HMs in Lijiang River water was compared with other rivers. Comparison shows that concentration of Mn, Co and Zn in Lijiang River is much higher than the world average background value, while $\mathrm{Cr}$, Cu and Cd values were in the similar level (Klavinš et al., 2000). Although Pb at Lijiang River in normal season was lower than the world background value, but it increased significantly in the rainstorm season which was 7 times of the world background (Klavinš et al., 2000). Compared with other rivers in China, Cr, Cu, As and Sb are generally lower in Lijiang River (Li and Zhang, 2009; Wang et al., 2017; Wu et al., 2009; Zeng et al., 2019; Zeng et al., 2015), which suggests a better quality of Lijiang water. However, high level of Zn in the rainstorm season of Lijiang River and Huaihe River (Wang et al., 2017) indicates that the water maybe polluted by Zn. The Co concentration was similar in the Zhujiang River during low flow and high flow seasons (Zeng et al., 2019), while Co increased 10 times in the rainstorm season of Lijiang River. In general, concentration of Cr, Mn, Co, Cu, As, Cd, Sb, and Pb in the water of Catalan River (Carafa et al., 2011), Douro River estuary (Ribeiro et al., 2018), and Calore River (Zuzolo et al., 2017) are higher than the Lijiang River water. Although Zn is much lower in Catalan River, but it keeps the similar level for the other three rivers.

\subsection{Spatial and temporal distribution of dissolved HMs}

Spatial and temporal distribution of dissolved HMs in Lijiang River were shown in Fig. 2. According to the variation characteristics of $\mathrm{Cr}$, Mn, $\mathrm{Co}$, $\mathrm{Cu}$, Zn, As, Cd, $\mathrm{Sb}$, and $\mathrm{Pb}$ in the normal season of Lijiang River, the HMs were divided into three groups. $\mathrm{Cr}, \mathrm{Cu}, \mathrm{Zn}, \mathrm{Co}$, and $\mathrm{Sb}$ belong to the first group, which concentrations increased successively from upstream to downstream. The distribution of $\mathrm{Cr}, \mathrm{Cu}, \mathrm{Zn}, \mathrm{Co}$, and $\mathrm{Sb}$ in Lijiang River may be affected by human activities, which is similar to the Han River (Li and Zhang, 2009). The second group were constituted by Mn, As, and Cd. High concentrations of Mn, As, and Cd were distributed uniformly in the upstream and middle reaches, and lower in the downstream areas. It probably due to exposure to dissolved parent rocks and minerals as well as agricultural sources (Chen et al., 2020). Pb as the only element in the third group was lower in the upstream and downstream areas, but higher in the middle reaches. This indicates that the mining industry and agricultural activities in the middle of the river may have a greater-impact on $\mathrm{Pb}$, but the dilution of the river leads to the decrease of concentration in the downstream areas (Li et al., 2009).

The categorization during the rainstorm season could be as follow. In the first group, distribution of Cr and Cd are more dispersed with high concentrations in the whole river. It suggests that the HMs may come from the mixture of natural and man-made sources. $\mathrm{Mn}, \mathrm{Cu}, \mathrm{Sb}$, and $\mathrm{Pb}$ in the second group were the lowest at the upstream areas, while high concentrations were mainly distributed in the middle and down streams. It is similar to the results of normal season, which HMs maybe influenced by dense human activities in the central areas. The third group including $\mathrm{Co}, \mathrm{Zn}$, and As which the concentration decreased gradually from upstream to downstream.

\subsection{Source identification of dissolved HMs}


The correlation and interaction of 9 dissolved HMs in two flow seasons in the Lijiang River Basin via Pearson correlation matrix is shown in Table S4. In normal season, $\mathrm{Mn}$ is significantly positively correlated with $\mathrm{Co}(0.658), \mathrm{Cu}(0.483)$ and $\mathrm{As}(0.385)$. And the HMs are positively correlated in pairs, such as Co$\mathrm{Cu}$ (0.701), Cu-As (0.554) and Co-As (0.420). Cd exhibited significant positive correlations with $\mathrm{Cu}(0.429)$ and $\mathrm{Co}(0.368)$. The results indicated its contribution from similar geochemical phenomenon. $\mathrm{Cr}$ was significantly positively correlated with $\mathrm{Zn}(0.670), \mathrm{Sb}(0.505)$ and $\mathrm{Cu}(0.446)$. $\mathrm{Pb}$ was weakly positively correlated with $\mathrm{Co}$ (0.434), $\mathrm{Cu}(0.373)$ and $\mathrm{Cd}(0.389)$. It suggested that the HMs may have similar sources in accordance (Xu et al., 2019). In rainstorm season, $\mathrm{Cr}$ and $\mathrm{Sb}(0.503), \mathrm{Cu}$ and $\mathrm{Mn}(0.714)$, are positively correlated remarkably. $\mathrm{Zn}$ is positively correlated with $\mathrm{Cd}(0.656)$ and $\mathrm{Co}(0.511)$, while $\mathrm{Co}$ is not correlated with $\mathrm{Cd}$, indicating that $\mathrm{Co}$ and $\mathrm{Cd}$ may come from different sources in the rainstorm season. There was a significant positive correlation between $\mathrm{Cd}$ and $\mathrm{Pb}(0.678)$, which may due to the release of $\mathrm{Cd}$ and $\mathrm{Pb}$ from sediments or rocks caused by the rainstorm. As shown weakly correlation with other $\mathrm{HMs}$ suggesting it comes from independent source.

The PCA of heavy metals in normal $(\mathrm{N})$ and rainstorm $(\mathrm{R})$ seasons resulted in three and four principal components (PCs), accounting for $69.85 \%$ and $75.84 \%$ of the total variance, respectively (PC, eigenvalue > 1), as shown in Table 2 and Figure S1. Aligned with previous studies conducted PCA of HMs in multiple water system changes was attributed to different variables (Rakotondrabe et al., 2018; Xiao et al., 2019). The principal components in the normal season $\left(P C 1_{N}, P C 2_{N}\right.$, and $\left.P C 3_{N}\right)$ accounted the total variance of $37.46 \%, 20.68 \%$, and $11.71 \%$, respectively. The results showed that PC1 ${ }_{N}$ had high load $(>0.75)$ on $\mathrm{Co}$ (0.820) and $\mathrm{Cu}(0.891)$, moderate load (0.75 0.5) of $\mathrm{Mn}(0.604)$ and $\mathrm{As}(0.698)$, and weak load $(0.5 \sim 0.3)$ for Cd (0.454), which was similar with the correlation results. In addition, $\mathrm{PC}_{\mathrm{N}}$ positively explained by the high load of $\mathrm{Cr}(0.746), \mathrm{Zn}(0.693)$, and $\mathrm{Sb}(0.507)$, whereas $\mathrm{PC} 3_{\mathrm{N}}$ was positively explained by high load of $\mathrm{Pb}(0.754)$. In rainstorm season, the $P C 1_{R}, P C 2_{R}, P C 3_{R}$, and $P C_{R}$ explained total variance of $27.71 \%, 21.60 \%, 15.18 \%$, and $11.35 \%$, respectively. $\mathrm{PC}_{\mathrm{R}}$ had high load on $\mathrm{Cd}(0.796)$ and $\mathrm{Pb}(0.797)$, but moderate load of $\mathrm{Mn}(0.683)$ and $\mathrm{Cu}(0.589)$. Furthermore, $\mathrm{PC} 2_{\mathrm{R}}$ was moderately loaded with $\mathrm{Zn}(0.698)$ and $\mathrm{Co}(0.648)$. $\mathrm{Cr}(0.673)$ and $\mathrm{Sb}(0.605)$ were moderately loaded by the $\mathrm{PC} 3_{\mathrm{R}}$. $\mathrm{PC} 4_{\mathrm{R}}$ had weak loading on As $(0.388)$.

Table 2

Principal component analysis for heavy metals

\begin{tabular}{|c|c|c|c|c|c|c|c|}
\hline \multirow[t]{2}{*}{ Elements } & \multicolumn{3}{|c|}{ Normal season } & \multicolumn{4}{|c|}{ Rainstorm season } \\
\hline & PC1 & PC2 & PC3 & PC1 & PC2 & РC3 & PC4 \\
\hline $\mathrm{Cr}$ & 0.551 & 0.746 & -0.064 & 0.223 & -0.457 & 0.673 & 0.243 \\
\hline $\mathrm{Mn}$ & 0.604 & -0.391 & -0.381 & 0.683 & -0.365 & -0.495 & 0.224 \\
\hline Co & 0.820 & -0.271 & -0.003 & 0.224 & 0.648 & 0.015 & 0.554 \\
\hline $\mathrm{Cu}$ & 0.891 & -0.065 & -0.034 & 0.589 & -0.408 & -0.409 & 0.379 \\
\hline $\mathrm{Zn}$ & 0.265 & 0.693 & 0.311 & 0.497 & 0.698 & 0.318 & 0.110 \\
\hline As & 0.698 & 0.025 & -0.395 & -0.202 & 0.175 & 0.041 & 0.388 \\
\hline $\mathrm{Cd}$ & 0.454 & -0.544 & 0.286 & 0.796 & 0.412 & 0.163 & -0.264 \\
\hline $\mathrm{Sb}$ & 0.492 & 0.507 & -0.003 & 0.151 & -0.557 & 0.605 & 0.192 \\
\hline $\mathrm{Pb}$ & 0.482 & -0.202 & 0.754 & 0.797 & -0.136 & 0.069 & -0.439 \\
\hline Eigenvalues & 3.373 & 1.862 & 1.053 & 2.494 & 1.944 & 1.366 & 1.022 \\
\hline$\%$ variance & 37.46 & 20.68 & 11.71 & 27.71 & 21.60 & 15.18 & 11.35 \\
\hline Cumulative variance & 37.46 & 58.14 & 69.85 & 27.71 & 49.31 & 64.49 & 75.84 \\
\hline
\end{tabular}

Based on the grouping of $\mathrm{PC}_{\mathrm{N}}$ and $\mathrm{PC} 1_{\mathrm{R}}$, the accumulation of $\mathrm{Mn}, \mathrm{Co}, \mathrm{Cu}$ and $\mathrm{Cd}$ in Lijiang River water in normal season is mainly from industrial emissions and urban pollution as well as natural erosion, while $\mathrm{Mn}, \mathrm{Cu}, \mathrm{Cd}$ and $\mathrm{Pb}$ in rainstorm season are the same. The concentration of $\mathrm{Co}$ and $\mathrm{Cu}$ in $\mathrm{PC} 1_{\mathrm{N}}$ is higher in the downstream, which may be the result of river scouring or the discharge of industrial waste water in the midstream. It was suggested that Co in surface water was mainly due to natural weathering of the rocks and subsequent soil action (Meng et al., 2016). In addition to the natural source of Co, ceramic, glass, paint, pigment, enamel, and electroplating may also increase the amount of $\mathrm{Co}$ in water. Cu concentration in water might cause by human activities such as metal smelting (Emenike et al., 2020). The concentration of other metals in $\mathrm{PC1} 1_{\mathrm{N}}$ is mainly concentrated in the upper and middle reaches. In general, Mn, As and $\mathrm{Cd}$ in the environment may come from rock weathering and river washing (Bai et al., 2019). Compared with the $\mathrm{PC} 1_{\mathrm{N}}$, the concentration of $\mathrm{Mn}$, $\mathrm{Cu}$, $\mathrm{Cd}$ and $\mathrm{Pb}$ of $\mathrm{PC} 1_{\mathrm{R}}$ is higher, and they are mainly distributed in the middle and lower stream of the river. It is possible that heavy metals from the sediment were released into the water due to rainstorm, with the same as evidenced by One-way ANOVA analysis (Tables 1 ). The presence of Pb in water may be attributed to the use of $\mathrm{Pb}$-acid batteries, industrial emissions and vehicle exhaust (Shahab et al., 2020).

$\mathrm{Cr}$ is positively correlated with $\mathrm{Zn}$ and $\mathrm{Sb}$ in $\mathrm{PC}{ }_{\mathrm{N}}$, which suggests that these heavy metal elements have similar sources. Moreover, the concentration of these elements is mainly concentrated in the lower reaches of rivers. In the middle reaches of the Lijiang River, tourism activities are intensive, and the adjacent industrial areas include electronic chemical materials and electrical appliances and Yingcai Science and Technology Park of Guilin National High-tech Zone. Some studies have shown that $\mathrm{Cr}$ compounds from human activities are discharged into coastal rivers and cause pollution (Chen et al., 2020; Rasool et al., 2016). However, there was no correlation between $\mathrm{Zn}$ and Sb. Zn in water mostly comes from industrial wastewater and agricultural activities (Kuang et al., 2016), while Sb is mainly derived from manufacturing processes such as mining, metal smelting, urban activities such as automobile exhaust, and waste 
incineration ( $\mathrm{Li}$ and Zhang, 2009). It suggests the likely sources of $\mathrm{Zn}$ and Sb come from agricultural and industrial activities, respectively. The concentration of $\mathrm{Zn}$ and $\mathrm{Co}$ in rainstorm season is mainly concentrated in the upper and middle reaches, which indicates that $\mathrm{PC} 2_{\mathrm{R}}$ may be controlled by natural sources.

The concentration of the HMs in rainstorm season is higher than that in normal season, possibly due to weathering and erosion caused by floods, which are natural causes. In addition to the natural source of $\mathrm{Co}$, ceramic, glass, paint, pigment, enamel, and electroplating may also increase the amount of Co in water

$\mathrm{PC}_{\mathrm{N}}$ has only a high load on $\mathrm{Pb}$. The presence of $\mathrm{Pb}$ in water may be derived from human activities, as mentioned, indicating that the PC $3_{\mathrm{N}}$ belongs to the second human source, which result is similar to the Xiangjiang River (Zeng et al., 2015). The variation concentration of $\mathrm{Cr}$ and $\mathrm{Sb}$ in rainstorm season ( $\mathrm{PC} 3_{\mathrm{R}}$ ) suggested they were influenced by human activities, including industrial wastewater, energy production, etc. The concentrations of $A_{s}$ in PC4 ${ }_{R}$ were higher in rainstorm season compared to normal. However, ANOVA analysis showed that rainstorm may have no significant association with the increase of As concentration. Mining activities and the use of pesticides may lead to arsenic pollution in water bodies (Zhang et al., 2019). Therefore, we conclude that the source of As may be anthropogenic factors in rainstorm season.

\subsection{WQI and health risk assessment}

The WQI values of water samples from different sites were shown in Fig. 3. In the present study, WQI in normal and rainstorm seasons were ranged from 0.50 7.96 and $6.17 \sim 20.82$, respectively. Therefore, Lijiang River water quality can be categorized as good (WQI value less than 50) and suitable for drinking. However, the WQI values in rainstorm season were obviously higher than the normal season, which indicates rainstorm promoted more HMs into the Lijiang River. During the rainstorm season, the fast-moving current may wash the contaminated soil and riverbed into the water (Jiang et al., 2017). The increased turbulent flow can also re-suspend the settled contaminants and HMs from the sediment and discharge them to the river. In Fig. 3, the WQI values of most upstream and midstream samples are higher than the average value in normal season, while in the rainstorm season, midstream and downstream samples are higher. It also demonstrates that heavy rains and scouring can affect river water quality, at least in terms of heavy metals. Based on the source identification analysis, the main factors of $\mathrm{HMs}$ in midstream and downstream were $\mathrm{Mn}, \mathrm{Cu}, \mathrm{Cd}, \mathrm{Pb}$ and $\mathrm{Sb}$. However, the WQI values of some sites in the midstream and downstream during normal season were lower than the average, but in rainstorm season were above the average. This finding suggests that dense human activities in the middle and lower reaches have a greater impact on water quality, which is similar with the results of interpolation. Therefore, we suggest that the decision-makers should pay attention to the prevention and control measures in these areas of the Lijiang River, including agricultural activities, industrial waste-water discharge and mining activities.

As shown in Table 3, the $\mathrm{HQ}_{\text {ingestion, }}, \mathrm{HQ}_{\text {dermal }}$, and $\mathrm{Hls}$ values, for adults and children, of all heavy metals are $<1$, indicating that the $\mathrm{HMs}$ (oral ingestion and skin absorption) in the Lijiang River are all below the hazard levels and have very-limited health effects. The values of $\mathrm{HQ}_{\text {ing, }}, \mathrm{HQ}_{\text {der, }}$, and $\mathrm{HIs}$ in $\mathrm{Lijiang}$ River water increased during rainstorm reason, except for $\mathrm{Cr}$, which indicates that the $\mathrm{HMs}$ in river due to heavy rainfall or human activities may lead to increasing health risks. As illustrated in Fig. 4, the $\mathrm{HQ}_{\text {ing }}, \mathrm{HQ}_{\text {der, }}$ and $\mathrm{Hls}$ values for children are higher than adults, which suggest children suffer greater risk from the exposure of HMs. The proportion of health risks for HMs in Lijiang River water is: $\mathrm{HI}$ for Children $(29.96 \sim 32.15)>\mathrm{HQ}_{\text {ing }}$ for children $(21.15 \sim 29.96)>\mathrm{HI}$ for adults $(17.89 \sim 20.04)>\mathrm{HQ}_{\text {ing }}$ for adults $(14.45 \sim 20.04)>\mathrm{HQ}_{\text {der }}$ for children $(0.01 \sim 1095)>\mathrm{HQ}_{\text {der }}$ for adults $(0 \sim 3.7)$. It shows that direct intake is the main exposure route. At some sampling sites with the maximal concentrations, the Hls of As for adults and children is 0.805 and 1.202 , respectively, which are relatively close to 1, during the rainstorm season. Therefore, we conclude that As might have potential non-carcinogenic risk to human health, especially during rainstorm season. It also reported high risks associated with As in other rivers (Emenike et al., 2020; Villa-Achupallas et al., 2018). Despite the potential risks, the results revealed that public health were not obviously affected by dissolved HMs in Lijiang River water in the current situation, agreed with the outcomes of WQI.

\section{Conclusions}

In this study, temporal and spatial distribution of dissolved $\mathrm{HMs}(\mathrm{Cr}, \mathrm{Mn}, \mathrm{Co}, \mathrm{Cu}, \mathrm{Zn}, \mathrm{As}, \mathrm{Cd}, \mathrm{Sb}$, and $\mathrm{Pb}$ ) in the water of Lijiang River from normal and rainstorm seasons were evaluated. According to the results, $\mathrm{Zn}$ and $\mathrm{Mn}$ were the most sufficient metals in both normal and rainstorm seasons. HMs concentrations in Lijiang water were under the guideline limits of China, the WHO, and the EPA. Results showed that the HMs concentrations increased during the rainstorm season, except for $\mathrm{Cr}$. Spatial and temporal distribution illustrated higher concentration of $\mathrm{Co}, \mathrm{Cu}, \mathrm{Cr}, \mathrm{Zn}, \mathrm{Sb}$, and $\mathrm{Pb}$ in the middle and lower streams during normal season, which might be affected by mining, industrial, and agricultural activities. Moreover, $\mathrm{Mn}, \mathrm{Cu}, \mathrm{Sb}$, and $\mathrm{Pb}$ came from the natural and man-made mixture sources in rainstorm season. It revealed that the increasing of $\mathrm{Mn}, \mathrm{Cu}, \mathrm{Cd}, \mathrm{Pb}, \mathrm{Co}$ and $\mathrm{Zn}$ during the high flow season should be caused by rainstorm scour. In general, the water quality was categorized as good-grade and can be used for drinking. However, it decreased to lower grades during the rainstorm season. Health risk assessment indicated most of the HMs in Lijiang River water were with limited health impacts, but As could be potential risks for public safety.

\section{Declarations}

Author Contribution Liming Deng: Writing - Original Draft, Data Curation, Software; Asfandyar Shahab: Data Curation, Writing- Reviewing and Editing, Methodology; He Xiao: Conceptualization, Data curation, Formal analysis, Writing - Original draft preparation; Jieyue Li: Software, Investigation, Visualization; Saeed Rad: Formal analysis, Writing- Reviewing and Editing; Jinping Jiang: Investigation, Visualization; GuoYu: Software, Validation; Pingping Jiang: Software, Validation; Hongwei Huang: Investigation, Resources; Xiangkui Li: Investigation, Resources; Bilal Ahmadd: Writing- Reviewing and Editing; Jamil Siddique: Writing- Reviewing and Editing.

Funding This research was supported by the Natural Science Foundation of Guangxi Province (Grant No. 2020GXNSFBA159040), Middle-aged and Young Teachers' Basic Ability Promotion Project of Guangxi (Grant No. 2020KY06036), and the National Natural Science Foundation of China (Grant No. 41661097).

Data Availability The data sets used and/or analyzed during the current study are available from the corresponding author (He Xiao) on reasonable request. 
Ethics approval and consent to participate Not applicable.

Consent for publication Not applicable.

Conflict of interest The authors declare no competing interest.

\section{References}

Ai, L., Shi, Z.H., Yin, W., Huang, X., 2015. Spatial and seasonal patterns in stream water contamination across mountainous watersheds: Linkage with landscape characteristics. J. Hydrol. 523, 398-408.

Alidadi, H., Tavakoly Sany, S.B., Zarif Garaati Oftadeh, B., Mohamad, T., Shamszade, H., Fakhari, M., 2019. Health risk assessments of arsenic and toxic heavy metal exposure in drinking water in northeast Iran. Environ. Health Prev. 24, 59.

Bai, J., Su, X., Yuan, W., 2019. Release of arsenic and iron in aquifer to groundwater under the variation of REDOX environment during bank infiltration: a case study in Huangjia groundwater source area, Northeastern China. Hum. Ecol. Risk Assess. 25, 1594-1614.

Carafa, R., Faggiano, L., Real, M., Munné, A., Ginebreda, A., Guasch, H., Flo, M., Tirapu, L., der Ohe, P.C.v., 2011. Water toxicity assessment and spatial pollution patterns identification in a Mediterranean River Basin District. Tools for water management and risk analysis. Sci. Total Environ. 409, 4269-4279.

Chai, N., Yi, X., Xiao, J., Liu, T., Liu, Y., Deng, L., Jin, Z., 2021. Spatiotemporal variations, sources, water quality and health risk assessment of trace elements in the Fen River. Sci. Total Environ. 757, 143882.

Chakraborti, D., Rahman, M.M., Das, B., Murrill, M., Dey, S., Chandra Mukherjee, S., Dhar, R.K., Biswas, B.K., Chowdhury, U.K., Roy, S., Sorif, S., Selim, M., Rahman, M., Quamruzzaman, Q., 2010. Status of groundwater arsenic contamination in Bangladesh: A 14-year study report. Water Res. 44, 5789-5802.

Chen, Q., Lu, Z., Yan, D., Wang, Q., Xin, S., 2020. Source analysis and health risk of heavy metals in the different seasons from Taizihe River, China. Acta Ecologica Sinica $40,64-71$.

Chowdhury, S., Mazumder, M.A.J., Al-Attas, O., Husain, T., 2016. Heavy metals in drinking water: Occurrences, implications, and future needs in developing countries. Sci. Total Environ. 569-570, 476-488.

Emenike, P.C., Neris, J.B., Tenebe, I.T., Nnaji, C.C., Jarvis, P., 2020. Estimation of some trace metal pollutants in River Atuwara southwestern Nigeria and spatiotemporal human health risks assessment. Chemosphere 239, 124770.

Ferreira, M.d.S., Fontes, M.P.F., Pacheco, A.A., Lima, H.N., Santos, J.Z.L., 2020. Risk assessment of trace elements pollution of Manaus urban rivers. Sci. Total Environ. 709, 134471.

Jiang, Y., Xie, Z., Zhang, H., Xie, H., Cao, Y., 2017. Effects of land use types on dissolved trace metal concentrations in the Le'an River Basin, China. Environ. Monit. and Assess. 189, 633.

Klavinš, M., Briede, A., Rodinov, V., Kokorite, I., Parele, E., Klavina, I., 2000. Heavy metals in rivers of Latvia. Sci. Total Environ. 262, $175-183$.

Kuang, C., Shan, Y., Gu, J., Shao, H., Zhang, W., Zhang, Y., Zhang, J., Liu, H., 2016. Assessment of heavy metal contamination in water body and riverbed sediments of the Yanghe River in the Bohai Sea, China. Environ. Earth Sci. 75, 1105.

Li, J., He, M., Han, W., Gu, Y., 2009. Analysis and assessment on heavy metal sources in the coastal soils developed from alluvial deposits using multivariate statistical methods. J. Hazard. Mater. 164, 976-981.

Li, S., Li, J., Zhang, Q., 2011. Water quality assessment in the rivers along the water conveyance system of the Middle Route of the South to North Water Transfer Project (China) using multivariate statistical techniques and receptor modeling. J. Hazard. Mater. 195, 306-317.

Li, S., Zhang, Q., 2009. Spatial Characterization of Dissolved Trace Elements and Heavy Metals in the Upper Han River (China) Using Multivariate Statistical Techniques. J. Hazard. Mater. 176, 579-588.

Ma, W., Huang, T., Li, X., Zhang, H., Ju, T., 2015. Impact of short-term climate variation and hydrology change on thermal structure and water quality of a canyon-shaped, stratified reservoir. Environ. Sci. Pollut. R. 22, 18372-18380.

Meng, Q., Zhang, J., Zhang, Z., Wu, T., 2016. Geochemistry of dissolved trace elements and heavy metals in the Dan River Drainage (China): distribution, sources, and water quality assessment. Environ. Sci. Pollut. R. 23, 8091-8103.

Olías, M., Nieto, J.M., Sarmiento, A.M., Cerón, J.C., Cánovas, C.R., 2004. Seasonal water quality variations in a river affected by acid mine drainage: the Odiel River (South West Spain). Sci. Total Environ. 333, 267-281.

Rakotondrabe, F., Ndam Ngoupayou, J.R., Mfonka, Z., Rasolomanana, E.H., Nyangono Abolo, A.J., Ako Ako, A., 2018. Water quality assessment in the BétaréOya gold mining area (East-Cameroon): Multivariate Statistical Analysis approach. Sci. Total Environ. 610-611, 831-844. 
Rasool, A., Farooqi, A., Xiao, T., Masood, S., Kamran, M.A., Bibi, S., 2016. Elevated levels of arsenic and trace metals in drinking water of Tehsil Mailsi, Punjab, Pakistan. J. Geochem. Explor. 169, 89-99.

Ribeiro, C., Couto, C., Ribeiro, A.R., Maia, A.S., Santos, M., Tiritan, M.E., Pinto, E., Almeida, A.A., 2018. Distribution and environmental assessment of trace elements contamination of water, sediments and flora from Douro River estuary, Portugal. Sci. Total Environ. 639, 1381-1393.

Shahab, A., Qi, S., Zaheer, M., 2019. Arsenic contamination, subsequent water toxicity, and associated public health risks in the lower Indus plain, Sindh province, Pakistan. Environ. Sci. Pollut. R. 26, 30642-30662.

Shahab, A., Zhang, H., Ullah, H., Rashid, A., Rad, S., Li, J., Xiao, H., 2020. Pollution characteristics and toxicity of potentially toxic elements in road dust of a tourist city, Guilin, China: Ecological and health risk assessment囚. Environ. Pollut. 266, 115419.

Shotyk, W., Bicalho, B., Cuss, C.W., Donner, M.W., Grant-Weaver, I., Haas-Neill, S., Javed, M.B., Krachler, M., Noernberg, T., Pelletier, R., Zaccone, C., 2017. Trace metals in the dissolved fraction $(<0.45 \mu \mathrm{m})$ of the lower Athabasca River: Analytical challenges and environmental implications. Sci. Total Environ. $580,660-$ 669.

Strady, E., Dinh, Q.T., Némery, J., Nguyen, T.N., Guédron, S., Nguyen, N.S., Denis, H., Nguyen, P.D., 2017. Spatial variation and risk assessment of trace metals in water and sediment of the Mekong Delta. Chemosphere 179, 367-378.

Teegavarapu, R.S.V., Chandramouli, V., 2005. Improved weighting methods, deterministic and stochastic data-driven models for estimation of missing precipitation records. J. Hydrol. 312, 191-206.

USEPA (United States Environmental Protection Agency), 2002. Child-specific Exposure Factors Handbook (EPA-600-P-00e002B). National Center for Environmental Assessment.

Villa-Achupallas, M., Rosado, D., Aguilar, S., Galindo-Riaño, M., 2018. Water quality in the tropical Andes hotspot: The Yacuambi river (southeastern Ecuador). Sci. Total Environ. 633, 50-58.

Wang, J., Liu, G., Liu, H., Lam, P.K.S., 2017. Multivariate statistical evaluation of dissolved trace elements and a water quality assessment in the middle reaches of Huaihe River, Anhui, China. Sci. Total Environ. 583, 421-431.

Wu, B., Zhao, D.Y., Jia, H.Y., Zhang, Y., Zhang, X.X., Cheng, S.P., 2009. Preliminary Risk Assessment of Trace Metal Pollution in Surface Water from Yangtze River in Nanjing Section, China. B. Environ. Contam. Tox. 82, 405-409.

Wu, W., Qu, S., Nel, W., Ji, J., 2020. The impact of natural weathering and mining on heavy metal accumulation in the karst areas of the Pearl River Basin, China. Sci. Total Environ. 734, 139480.

Xiao, H., Shahab, A., Xi, B., Chang, Q., You, S., Li, J., Sun, X., Huang, H., Li, X., 2021. Heavy metal pollution, ecological risk, spatial distribution, and source identification in sediments of the Lijiang River, China. Environ. Pollut. 269, 116189.

Xiao, J., Wang, L., Deng, L., Jin, Z., 2019. Characteristics, sources, water quality and health risk assessment of trace elements in river water and well water in the Chinese Loess Plateau. Sci. Total Environ. 650, 2004-2012.

Xu, D., Wang, Y., Zhang, R., Guo, J., Zhang, W., Yu, K., 2016. Distribution, speciation, environmental risk, and source identification of heavy metals in surface sediments from the karst aquatic environment of the Lijiang River, Southwest China. Environ. Sci. Pollut. R. 23, 9122-9133.

Xu, J., Zhuang, Q., Fu, Y., Huang, Y., Sun, Z., Liu, Z., 2019. Spatial distribution, pollution levels, and source identification of heavy metals in wetlands of Suzhou Industrial Park, China. Wetl. Ecol. Manag. 27, 743-758.

Zeng, J., Han, G., Wu, Q., Yang, T., 2019. Geochemical characteristics of dissolved heavy metals in Zhujiang River, Southwest China: Spatial-temporal distribution, source, export flux estimation, and a water quality assessment. PeerJ 7, e6578.

Zeng, X., Liu, Y., You, S., Zeng, G., Tan, X., Hu, X., Hu, X., Huang, L., Li, F., 2015. Spatial distribution, health risk assessment and statistical source identification of the trace elements in surface water from the Xiangjiang River, China. Environ. Sci. Pollut. R. 22, 9400-9412.

Zhang, L., Yang, H., Tang, J., Qin, X., Yu, A.Y., 2014. Attenuation of arsenic in a karst subterranean stream and correlation with geochemical factors: A case study at Lihu, South China. J. Environ. Sci. 26, 2222-2230.

Zhang, Y., Xu, B., Guo, Z., Han, J., Li, H., Jin, L., Chen, F., Xiong, Y., 2019. Human health risk assessment of groundwater arsenic contamination in Jinghui irrigation district, China. J. Environ. Manage. 237, 163-169.

Zhao, X.-M., Yao, L.-A., Ma, Q.-L., Zhou, G.-J., Wang, L., Fang, Q.-L., Xu, Z.-C., 2018. Distribution and ecological risk assessment of cadmium in water and sediment in Longjiang River, China: Implication on water quality management after pollution accident. Chemosphere 194, 107-116.

Zuzolo, D., Cicchella, D., Catani, V., Giaccio, L., Guagliardi, I., Esposito, L., De Vivo, B., 2017. Assessment of potentially harmful elements pollution in the Calore River basin (Southern Italy). Environ. Geochem. Hlth. 39, 531-548. 


\section{Figures}

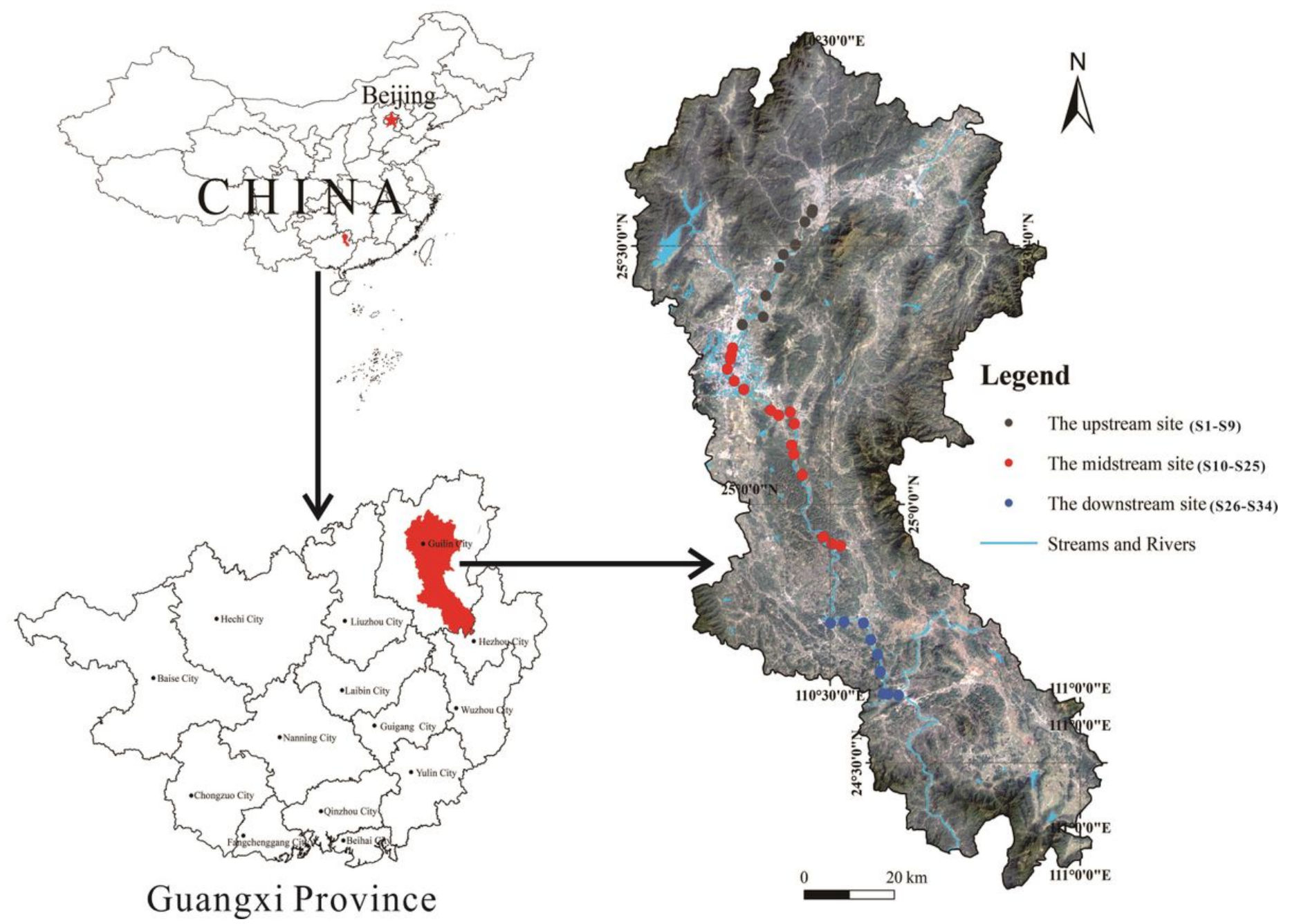

Figure 1

Spatial distributions of dissolved heavy metals in Lijiang River water. a) normal season; b) rainstorm season. Note: The designations employed and the presentation of the material on this map do not imply the expression of any opinion whatsoever on the part of Research Square concerning the legal status of any country, territory, city or area or of its authorities, or concerning the delimitation of its frontiers or boundaries. This map has been provided by the authors. 


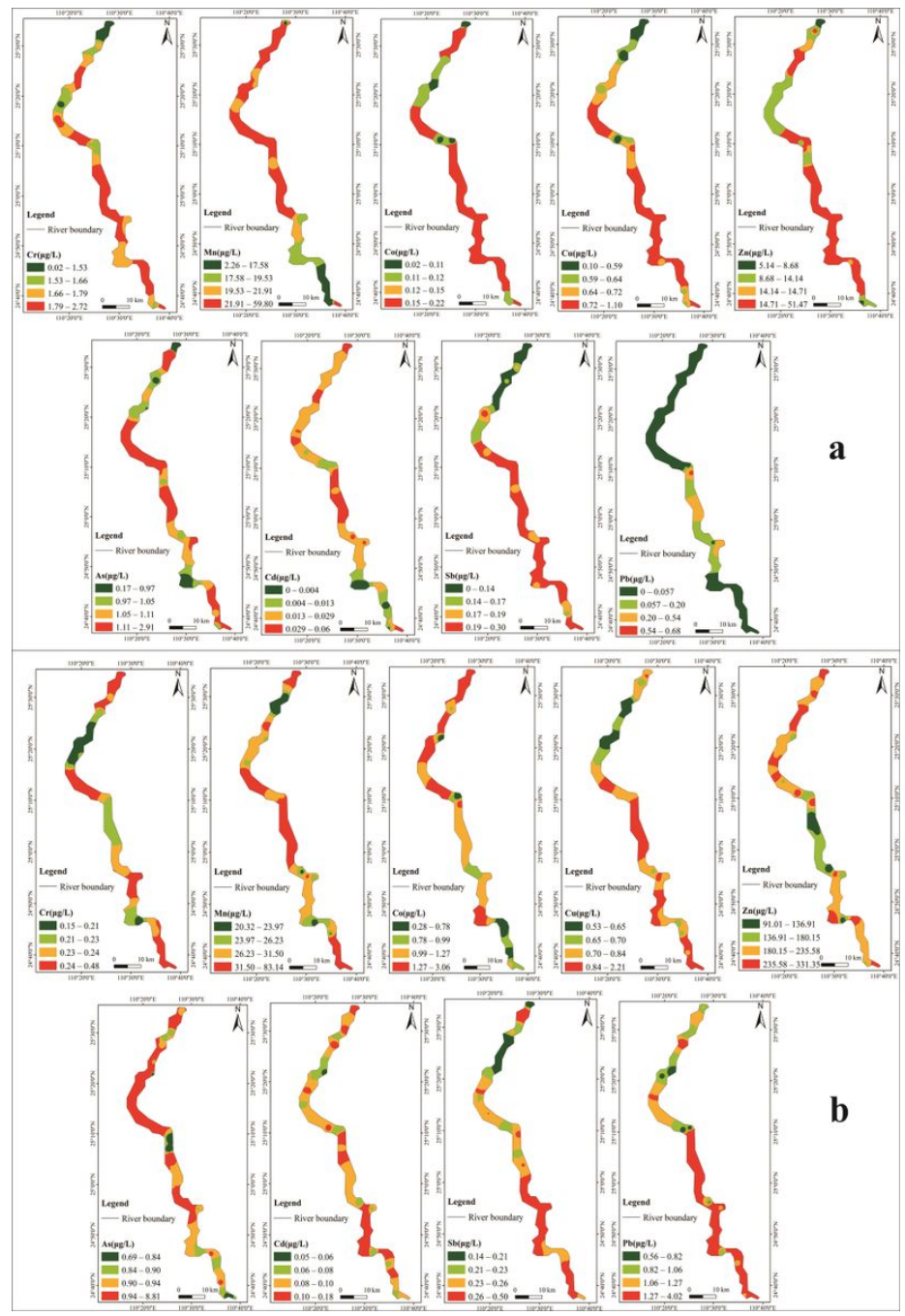

Figure 2

Spatial distributions of dissolved heavy metals in Lijiang River water. a) normal season; b) rainstorm season. Note: The designations employed and the presentation of the material on this map do not imply the expression of any opinion whatsoever on the part of Research Square concerning the legal status of any country, territory, city or area or of its authorities, or concerning the delimitation of its frontiers or boundaries. This map has been provided by the authors. 


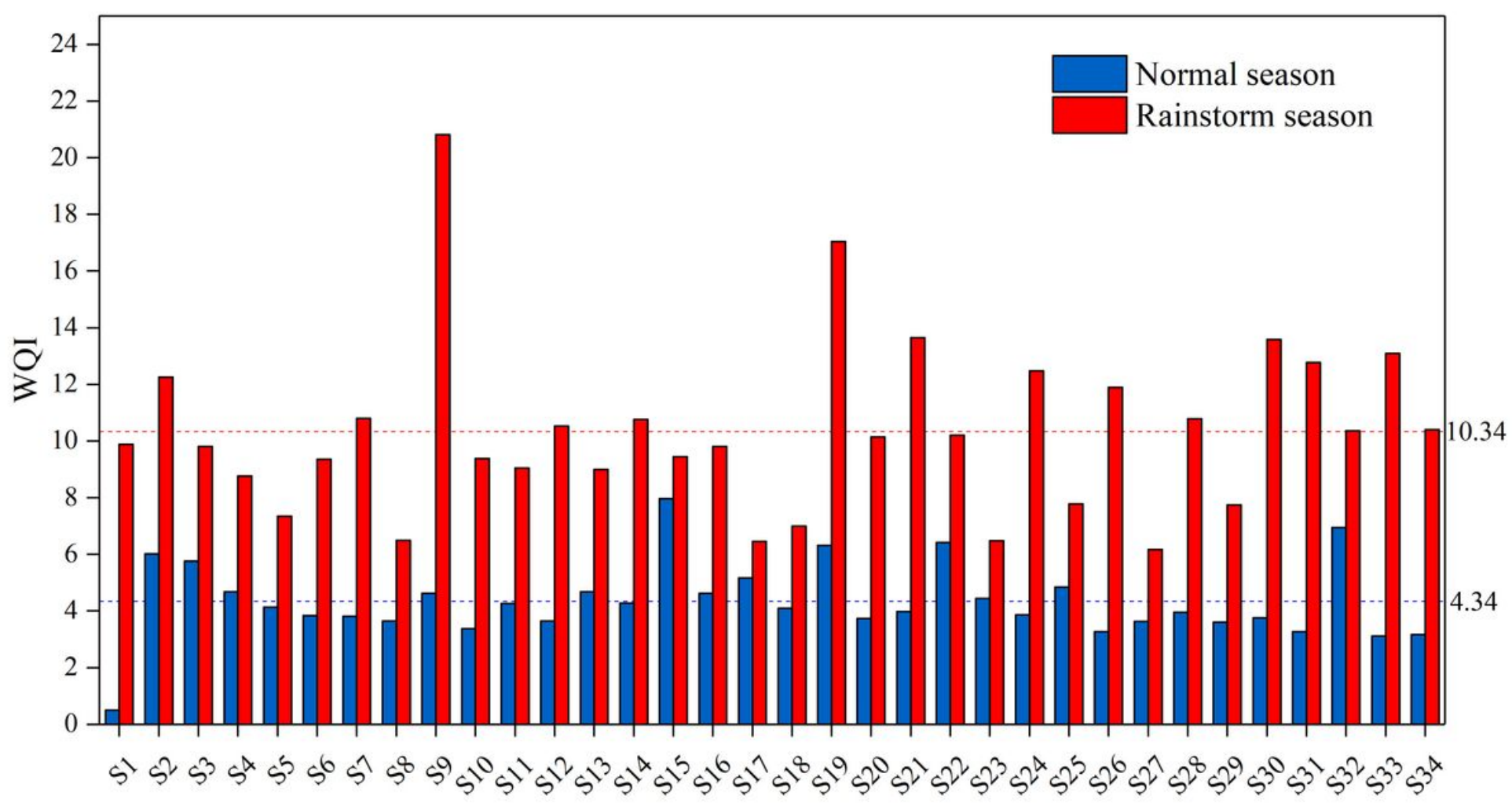

Figure 3

Water quality index (WQI) values of Lijiang River water. The blue line presents the median value of normal season, the red line presents the median value rainstorm season.

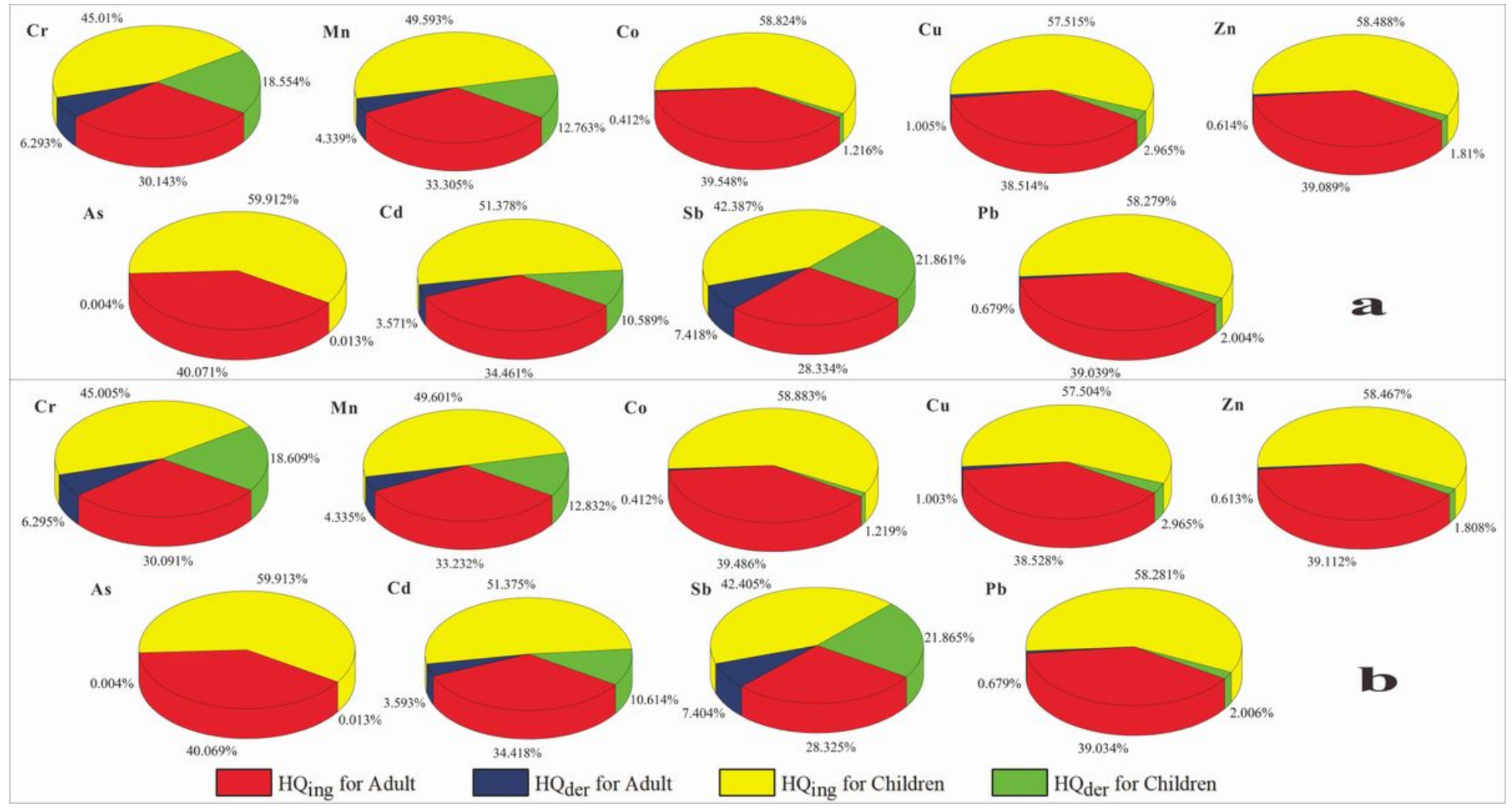

Figure 4

Pie chart of health risk assessment in Lijiang River water. a) normal season; b) rainstorm season.

\section{Supplementary Files}


This is a list of supplementary files associated with this preprint. Click to download.

- SupplementaryMaterial.doc

Page 13/13 